\title{
KONSEP MANAJEMEN PERPUSTAKAAN DALAM MENINGKATKAN MINAT BACA SISWA DI MTs NEGERI 1 PURWOREJO
}

\author{
Rosa Sugesti Hadi, Shofa Aulia Kumala \\ Sekolah Tinggi Agama Islam An-Nawawi, Purworejo \\ Email : rosasugesti7@gmail.com,Shofaaulia@gmail.com
}

\begin{abstract}
The library is an institution that manages the collection of written works, printed works, and / or recorded works in a professional manner with a standardized system to meet the educational, research, preservation, information, and recreation needs of the visitors. Library management is the implementation of management functions to empower management elements which include all processes from planning, organizing, mobilizing, to supervision. The nature of management is basically basically optimizing human, material, and budget contributions to achieve organizational goals. interest in reading is the tendency of the soul to encourage someone to do something about reading. Interest in reading is indicated by a strong desire to carry out reading activities. This research uses a descriptive qualitative approach. In this study, researchers chose the MTs Negeri 1 Purworejo Library. This research was conducted for one month from January 13, 2020 to February 13, 2020. To obtain and collect accurate and necessary data in this research activity, the researchers determined the respondents (actors) to be examined 1). Head master; 2). Head of Library; 3). Deputy Head of Madrasa Curriculum Section 4) Representatives of grades 7-9.The results of the study are the concept of library management in increasing students' interest in reading at MTs Negeri 1 Purworejo still in the process of development. The management used is still in the management towards a better direction, so it is expected that students can be more comfortable to visit the library so as to increase students' insight and interest in reading at MTs Negeri 1 Purworejo.
\end{abstract}

Keywords: library management, interest in reading 


\begin{abstract}
ABSTRAK
Perpustakaan adalah institusi pengelola koleksi karya tulis, karya cetak, dan/atau karya rekam secara profesional dengan sistem yang baku guna memenuhi kebutuhan pendidikan, penelitian, pelestarian, informasi, dan rekreasi para pemustaka. Manajemen perpustakaan merupakan pelaksanaan fungsi manajemen untuk memberdayakan unsur manajemen yang meliputi segala proses dari perencanaan, pengorganisasian, penggerakan, sampai pengawasan. Hakikat manajemen secara sederhana pada dasarnya adalah mengoptimalkan kontribusi manusia, material, anggaran untuk mencapai tujuan organisasi. minat baca merupakan kecenderungan jiwa yang mendorong seseorang berbuat sesuatu terhadap membaca. Minat baca ditunjukkan dengan keinginan yang kuat untuk melaku kegiatan membaca.

Penelitian ini menggunakan pendekatan kualitatif deskriptif. Pada penelitian ini, peneliti memilih Perpustakaan MTs Negeri 1 Purworejo. Penelitian ini dilaksanakan selama satu bulan terhitung dari 13 Januari 2020-13 Februari 2020. Untuk mendapatkan dan mengumpulkan data yang akurat dan yang diperlukan dalam kegiatan penelitian ini, maka peneliti menetapkan responden (pelaku) yang akan diteliti 1). Kepala Madrasah; 2). Kepala Perpustakaan; 3). Wakil Kepala Madrasah Bagian Kurikulum 4) Perwakilan siswa kelas 7-9.

Hasil penelitian yaitu konsep manajemen perpustakaan dalam meningkatkan minat baca siswa di MTs Negeri 1 Purworejo masih dalam proses perkembangan. Manajemen yang digunakan masih dalam pengelolaan menuju arah yang lebih baik, sehingga diharapkan siswa bisa lebih nyaman untuk berkunjung di perpustakaan sehingga dapat meningkatkan wawasan serta minat baca siswa di MTs Negeri 1 Purworejo.
\end{abstract}

Kata Kunci : manajemen perpustakaan, minat baca 


\section{PENDAHULUAN}

Perpustakaan merupakan salah satu bentuk organisasi sumber belajar yang meliputi proses perencanaan, pengorganisasian, penggerakan dan pengawasan dalam suatu unit kerja. Perpustakaan hadir sebagai sarana menumbuhkembangkan potensi membaca pada seseorang. Dimana ketika seseorang gemar membaca maka wawasannya akan terbuka dengan luas. Selain itu, perpustakaan merupakan salah satu pelestari bahan pustaka sebagai hasil budaya serta memiliki fungsi sebagai sumber informasi ilmu pengetahuan dan teknologi dalam rangka mencerdaskan kehidupan bangsa.

Dewasa ini minat baca di kalangan masyarakat khususnya kalangan siswa berkurang. Ini terjadi karena semakin majunya teknologi informasi serta situs-situs online di Indonesia. Siswa lebih banyak memilih bermain game online daripada membaca buku di perpustakaan. Oleh karena itu, seiring berkembangnya zaman sebuah perpustakaan di desain lebih modern agar tetap eksis dan bisa menjadi srana penunjang pembelajaran di sekolah (adi wibowo 2019).

Manajemen pepustakaan sangat penting dalam hal menumbuhkan minat baca di kalangangan siswa. Sebagi contoh perpustakaan yang terdapat di MTs Negeri 1 Purworejo. Di perpustakaan tersebut mencoba untuk memadukan cara klasik dengan cara modern dimana semua akses perpustakaan tersambung di internet (Wibowo 2018). Oleh karena itu, siswa diharapkan tetap gemar membaca serta tetap update dengan informasi teknologi dan informasinya. Dalam hal ini penulis ingin mencoba meneliti perpustakaan MTs Negeri 1 Purworejo yang berkaitan dengan manajemen perpustakaan dalam meningkatkan minat baca siswa di MTs Negeri 1 Purworejo. 


\section{KAJIAN PUSTAKA}

1. Pengertian Perpustakaan

Secara tradisional arti dari perpustakaan adalah sebuah koleksi buku dan majalah. Perpustakaan dapat juga diartikan sebagai koleksi pribadi perseorangan, namun lebih umum dikenal sebagai koleksi besar yang dibiayai dan dioperasikan oleh sebuah kota atau institusi yang dimanfaatkan oleh masyarakat yang rata-rata tidak mampu membeli sekian banyak buku atas biaya sendiri. Dalam undang undang perpustakaan disebutkan, bahwa Perpustakaan adalah institusi pengelola koleksi karya tulis, karya cetak, dan/atau karya rekam secara profesional dengan sistem yang baku guna memenuhi kebutuhan pendidikan, penelitian, pelestarian, informasi, dan rekreasi para pemustaka.(Rokan 2017)

Perpustakaan sebagai suatu lembaga pendidikan dan lembaga informasi akan memiliki kinerja yang baik apabila ditunjang dengan manajemen yang memadai. Dengan adanya manajemen, seluruh aktivitas lembaga akan mengarah pada upaya pencapaian tujuan yang telah direncanakan, sehingga seluruh elemen dalam suatu lembaga tersebut akan berusaha memfungsikan diri sesuai kebijakan lembaga/perpustakaan. Manajemen sendiri merupakan proses perencanaan, pengorganisasian, pengarahan, dan pengawasan, usaha-usaha para anggota organisasi dan penggunaan sumber daya organisasi lainnya untuk mencapai tujuan organisasi yang telah ditetapkan.Andi Ibrahim, “Konsep Dasar Manajemen Perpustakaan Dalam Mewujudkan Mutu Layanan Prima Dengan Sistem Temu Kembali Informasi Berbasis Digital," Desember vol.2, no. No.2 (2014), hlm. 129-38. 
Manajemen Perpustakaan yang baik akan memotivasi siswa untuk memanfaatkan perpustakaan (Subaidi 2019). Manajemen perpustakaan merupakan pelaksanaan fungsi manajemen untuk memberdayakan unsur manajemen. Hakikat manajemen secara sederhana pada dasarnya adalah mengoptimalkan kontribusi manusia, material, anggaran untuk mencapai tujuan organisasi. Sedangkan menurut Lasa, Manajemen perpustakaan adalah upaya pencapaian tujuan dengan pemanfaaatan sumbar daya manusia, informasi, sistem dan sumber dana dengan memperhatikan fungsi manajemen, peran, dan keahlian.Rustam Meriani, “HIJRI-Jurnal Manajemen Pendidikan Dan Keislaman," Manajemen Perpustakaan 7, no. 1 (2018), hlm. 51. dari pengertian diatas, dapat disimpulkan bahwa untuk mencapai tujuan diperlukan sumber daya manusia (human resources) dan sumber nonmanusia (non human resources) yang berupa sumber dana, teknik, fisik, perlengkapan, alam, informasi, ide, peraturan-peraturan, dan teknologi. Sumber daya tersebut dikelola dengan baik melalui proses manajemen, yang meliputi : perencanaan, pengorganisasian, penggerakan, dan pengawasan.1

Dalam hal ini, perpustakaan merupakan suatu lembaga yang mengelola sumber informasi yang menduduki posisi penting dalam pendidikan dan tempat pelatihan bagi seseorang yang peduli dengan ilmu pengetahuan, baik di lingkungan sekolah maupun di kalangan masyarakat pada umumnya (Eko Prayogo 2019). Demikian juga dengan adanya perpustakaan sekolah yang mempunyai tujuan sebagai sumber informasi dan pengetahuan di lingkungan sekolah juga digunakan sebagai tempat awal untuk mengembangkan minat dan budaya membaca bagi para siswa. Menurut Susanto, membaca merupakan proses menangkap atau

\footnotetext{
${ }^{1}$ Ibid., hlm. 52
} 
memperoleh konsep-konsep yang dimaksud oleh oleh pengarangnya, menginterpretasi (Indhra Musthofa 2019), mengevaluasi konsep-konsep pengarang dan merefleksikan atau bertindak seperti yang dimaksud dalam konsep itu. Selanjutnya pendapat lain yaitu seperti yang diungkapkan oleh Darmono, menyatakan bahwa minat baca merupakan kecenderungan jiwa yang mendorong seseorang berbuat sesuatu terhadap membaca. Minat baca ditunjukkan dengan keinginan yang kuat untuk melakukan kegiatan membaca.

Demi mewujudkan minat baca tersebut, peran sekolah sangat diharapkan membantu untuk menumbuhkembangkannya melalui perpustakaan sekolah. Perpustakaan sekolah merupakan unit kerja dan bagian integral dari lembaga pendidikan yang berupa tempat penyimpanan koleksi bahan pustaka yang dikelola dan diatur menurut sistem tertentu untuk digunakan dalam menunjang kegiatan belajar dan mengajar di sekolah untuk kepentingan proses pembelajaran di sekolah sesuai jenjang sekolah.Pranandia Popi Pitaloka, "Memupuk Minat Baca Anak," IQRA : Jurnal Ilmu Perpustakaan Dan Informasi (e-Journal) 12, no. 2 (2019), hlm. 26-29 Dengan demikian, perpustakaan sekolah bisa digunaka sebagai sarana pendukung belajar siswa sehingga para siswa bisa mengembangkan potensi yang dimilikinya serta meningkatkan minat baca siswa tersebut.

Adapun penyebab rendahnya minat baca pada siswa dapat dipengaruhi oleh beberapa faktor, diantaranya sebagai berikut :

a) Lemahnya Dukungan dan Perhatian dari Kepala Sekolah Tidak ada program dari sekolah yang dapat mendukung kegiatan yang berhubungan dengan minat baca serta alokasi dana yang kurang memadai sehingga menghambat proses pengelolaan perpustakaan. Dana sangat diperlukan dalam kegiatan perpustakaan selain pengadaan, pengolahan 
dan pelayanan, juga ada kegiatan perawatan dan perbaikan baik koleksi maupun sarana prasarana lainnya.

b) Kurangnya Pengelolaan Perpustakaan Sekolah

Koleksi perpustakaan kurang menarik yang hanya berisi buku pelajaran membuat siswa malas untuk membaca. Layanan yang hanya berupa pelayanan sirkulasi yaitu layanan peminjaman, pengembalian dan perpanjangan bahan pustaka untuk dibawa pulang maupun baca ditempat. Petugas perpustakaan yang belum semua memiliki kualifikasi akademik perpustakaan terkadang hanya diisi guru bidang studi.

c) Kemajuan Teknologi

Perkembangan teknologi terutama gadget membuat anak lebih tertarik bermain gadget. Bentuknya yang fleksibel dapat dibawa kemana saja, kecil dan memiliki fitur yang banyak seperti Google, Yahoo, Youtube, game online, facebook, instagram, twiter, atau lainnya membuat informasi dari dunia mana saja dapat diketahui. Bahkan saat mengerjakan PR pun anak lebih suka menelusurnya melalui internet dari pada membaca buku.

d) Acara Hiburan

Berkembangnya pusat permainan, mall, kafe, karoake, atau sejenis lainnya. Tempat yang nyaman bahkan terdapat fasilitas wifi gratis membuat mereka betah berlama-lama di area ini.

e) Acara Televisi

Maraknya acara televisi yang bersifat kartun, komedi, sinetron, dan sebagainya juga membuat anak betah untuk berlama lama di depan televisi. Bahkan tayangan yang bersifat harian atau mingguan menjadi kegiatan rutinitas bagi mereka.

f) Kurangnya Dukungan Keluarga dan Lingkungan

Rendahnya minat baca di kalangan anak dapat disebabkan oleh kondisi keluarga yang tidak mendukung, terutama dari orang tua yang tidak 
mencontohkan kegemaran membaca kepada anak-anak mereka (Moch. Tohet 2019). Selain itu, kurangnya perhatian dan pengawasan orang tua terhadap kegiatan anak-anaknya. Minimnya ketersediaan bahan bacaan di rumah juga dapat membuat anak kurang berminat pada kegiatan membaca. Selain dari sisi keluarga, terdapat juga pengaruh dari lingkungan. Karena pengaruh ajakan yang begitu kuat dari teman, anak lebih memilih bermain dengan temantemannya dibanding membaca buku. Ketersediaan waktu yang kurang, membuat anak tidak sempat membaca. Seperti anak yang bersekolah sampai sore hari, tentu sebagian besar waktu dalam sehari sudah banyak dihabiskan di sekolah. Kesempatan memiliki waktu luang sangat terbatas. Apalagi jika masih ada kegiatan-kegiatan rutin yang mereka jalani setelah pulang sekolah. Kalaupun masih ada sisa waktu, mereka lebih memanfaatkan untuk bersantai dan melepas lelah.2

\section{METODE PENELITIAN}

Penelitian ini menggunakan pendekatan kualitatif deskriptif. Penelitian deskriptif adalah suatu bentuk penelitian yang paling dasar (Adi Wibowo 2019). Ditujukan untuk mendeskripsikan atau menggambarkan fenomena-fenomena yang ada, baik fenomena yang bersifat alamiah ataupun rekayasa manusia. Pada penelitian ini, peneliti memilih Perpustakaan MTs Negeri 1 Purworejo. Penelitian ini dilaksanakan selama satu bulan terhitung dari 13 Januari 2020-13 Februari 2020. Untuk mendapatkan dan mengumpulkan data yang akurat dan yang diperlukan dalam kegiatan penelitian ini, maka peneliti menetapkan responden (pelaku) yang akan diteliti 1). Kepala Madrasah; 2). Kepala Perpustakaan; 3). Wakil Kepala Madrasah Bagian Kurikulum Dalam penelitian ini untuk memperoleh data, peneliti menggunakan dua jenis sumber data:

${ }^{2}$ Ibid.., hlm. 31-33 
a) Data primer, data yang diperoleh dari lapangan seperti fasilitas, kepala perpustakaan, Kepala Madrasah dan Wakil Kepala Madrasah Bagian Kurikulum (Muhlil Musolin 2019).

b) Data sekunder, yaitu data yang diperoleh dari perpustakaan, tentang literatur-literatur yang berkaitan dengan permasalahan yang sedang dibahas. Pengumpulan data dalam penelitian ini dilakukan langsung oleh peneliti melalui: observasi, wawancara, dan dokumentasi (Subaidi 2019).

Analisis data adalah proses mengorganisasian dengan data ke dalam pola, kategorisasi, dan satuan uraian dasar sehingga ditemukan tema dan hipotesa kerja seperti yang disarankan data. Data yang telah diorganisasi ke dalam satu pola dan membuat kategorinya, maka data diolah dengan menggunakan analisis data model Milles dan Hubbberman, dalam Syahrum dan Salim dengan : a) Reduksi Data; b) Sajian data; c) Penarikan Kesimpulan.

\section{HASIL PENELITIAN DAN PEMBAHASAN}

Di dalam perpustakaan MTs N 1 Purworejo memiliki manajemen yang belum lama dilaksanakan. Perpustakaan merupakan salah satu fasilitas penting bagi lembaga pendidikan tak terkecuali MTs N 1 Purworejo. Namun, suatu perpustakaan juga tidak akan berjalan baik tanpa adanya suatu pengeloalaan dalam mengaturnya.Oleh karena itu, dibutuhkan manajemen perpustakaan. Perpustakaan MTs N 1 Purworejo ini memiliki struktur organisasi yang berperan mengelola keseluruhan dari perpustakaan. Struktur tersebut diketuai oleh Bapak Fattah Ismail, S. Ag. pada awal tahun 2018, sedangkan para anggotanya. Berikut struktur organisasi mikro perpustakaan MTs N 1 Purworejo tahun pelajaran 2019/2020, yaitu : 


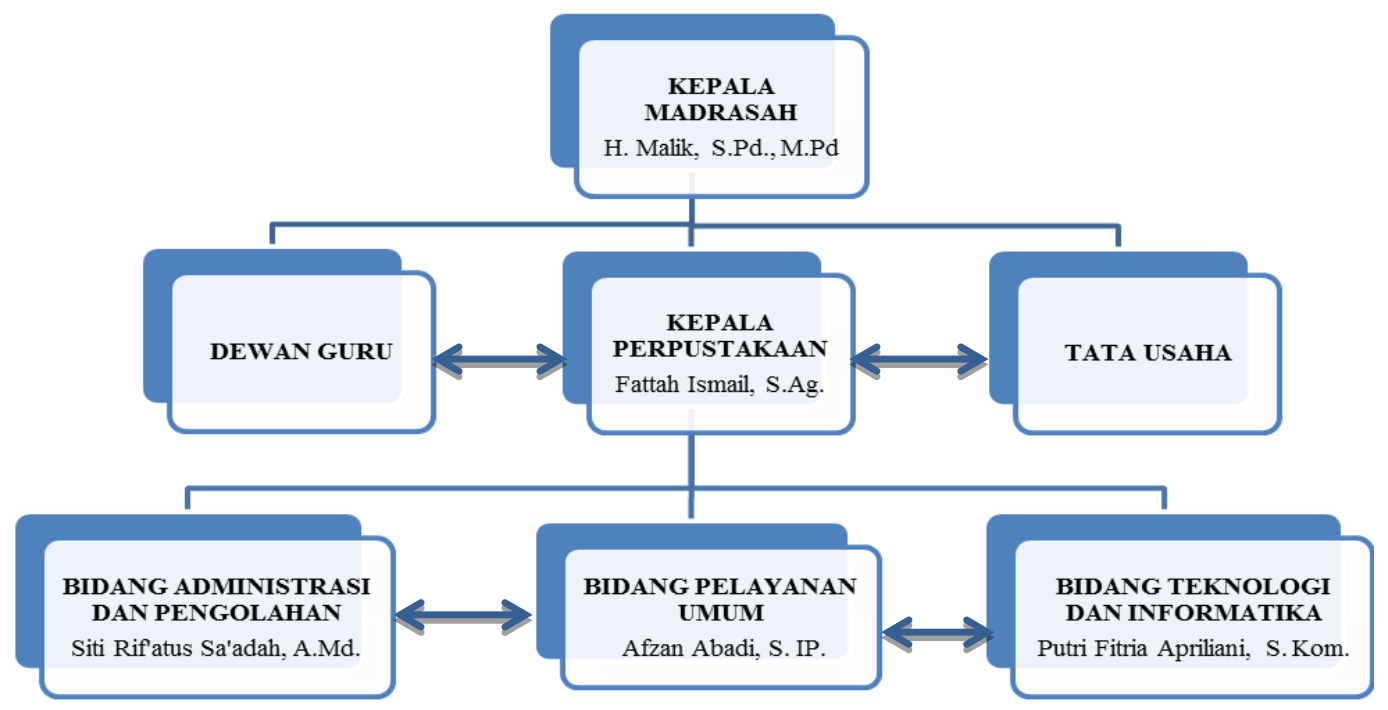

(a) Struktur Organisasi Mikro Perpustakaan MTs N 1 Purworejo

Pihak perpustakaan ini yang bertanggung jawab atas pengelolaan perpustakaan. Manajemen perpustakaan MTs N 1 Purworejo ini dikembangkan guna akreditasi madrasah oleh Kemenag, yaitu

Menambahkan buku-buku perpustakaan;

Menambahkan tenaga perpustakaan, khususnya yang berasal dari lulusan sarjana perpustakaan;

Program yang dilaksanakan perpustakaan ini tidak berbeda dengan perpustakaan pada umumnya, yaitu peminjaman dan pengembalian buku. Program peminjaman buku terdiri dari peminjaman buku secara kelas (bekerja sama dengan guru mata pelajaran), mandiri (jadwalnya random), maupun jangka waktu satu tahun. Terdapat peraturan dari Kemendikbud untuk K-13 adalah setiap siswa berhak mendapatkan satu buku untuk dimiliki secara pribadi (Hadi Santoso 2019). 
Namun, melihat kondisi MTs N 1 Purworejo masih kekurangan dalam memfasilitasi buku-buku di perpustakaan, menjadikan setiap siswa hanya mendapat kesempatan meminjam dengan kurun waktu 1 tahun. Terkadang juga ada yang masih mendapatkan satu buku untuk setiap meja atau satu buku untuk dua siswa, dengan menetapkan nomor buku kepada setiap siswa. Menurut Ibu Siti Rif'atus Sa'adah selaku salah satu pengelola mengatakan bahwa standar perpustakaan yang baik adalah bukan yang megah, tetapi yang mampu memenuhi kebutuhan buku para peserta didik .

Kemudian untuk peminjaman buku atas nama pribadi, juga masih belum kondusif, seperti belum diperbolehkannya peminjaman buku non fiksi, belum ada pembatasan banyaknya buku bagi setiap siswa, serta belum ada pembatasan waktu peminjaman. Hal ini karena perpustakaan ini baru mulai dirintis kembali dua tahun terakhir (2018) setelah pengelola perpustakaan terdahulu keluar dari MTs N 1 Purworejo, sehingga kesulitan dalam mengawali dan merevisinya kembali dengan karyawan yang terbatas serta kebanyakan masih baru.

Walaupun banyak kendala yang dihadapi, tetapi pihak perpustakaan terus berusaha memajukan dan berharap dapat mengembangkan perpustakaan secara bertahap. Dibandingkan kondisi perpustakaan dahulu, kondisi perpustakaan juga ada kemajuan sedikit, yaitu program peminjaman dan pengembalian buku sudah dilakukan dengan memasukkan nomor ID sesuai dengan barcode kartu setiap siswa ke dalam komputer. Sedangkan dahulu, masih dilakukan secara manual, dimana program peminjaman dan pengembalian buku menggunakan kartu tulis tangan (berbentuk kartu dari kertas). Pengelola perpustakaan juga membuat peraturan-peraturan bagi pengunjung perpustakaan khususnya para siswa. Peraturan-peraturan tersebut, seperti : tidak merusak ataupun menghilangkan buku yang sudah dipinjam. Apabila hal ini terjadi, maka akan 
mendapat konsekuensi harus mengganti buku tersebut dengan buku baru atau membayar dana ganti senilai Rp 50.000 tiap buku.

Koleksi buku di perpustakaan MTs N 1 Purworejo berkisar 5.000 eksemplar. Buku-buku tersebut berasal dari dana BOS sebesar $5 \%$ untuk pengembangan perpustakaan, pemerintah dalam bentuk uang tunai, dana DIPA (bagian BOS) untuk pembelian buku pelajaran, dapat pula dari sumbangan buku dari beberapa guru, karyawan, atau siswa. Untuk penfilteran buku-buku lama belum dilakukan karena buku-buku pelajaran KTSP yang kini masih dibutuhkan sebagian guru sebagai bahan referensi pembelajaran di kelas, padahal saat ini kurikulum telah berganti menjadi K-13. Sebagian guru yang masih menggunakan buku-buku pelajaran KTSP beralasan bahwa buku-buku tersebut lebih lengkap daripada buku-buku K-13. Kunjungan siswa dilayani dari mulai pembelajaran berlangsung untuk menunjang lancarnya pembelajaran.

Pengelola perpustakaan juga memiliki program evaluasi secara rutin dengan mengadakan rapat biasa yang diikuti pihak pengelola perpustakaan sendiri, sedang untuk rapat format bersama kepala dan guru-guru madrasah masih jarang atau diadakan ketika ada permintaan dari atasan. Tugas pengelola perustakaan sebenarnya hanya konsentrasi pada perpustakaan, tetapi di MTs N 1 Purworejo terkadang juga ikut serta membantu penyusunan rapor peserta didik yaitu pengembangan aplikasi madrasah. Berdasarkan penyajian data lapangan diatas, manajmen perpustakaan di MTs Negeri 1 Purworejo yang sudah dijalankan masih secara tradisional baik dari pelayanan, pengklisifikasian koleksi, katalog buku, dan inventaris buku. Oleh karena itu dari pihak perpustakaan sedang menjalankan dan mengembangkan program baru sehingga para siswa tertarik untuk datang ke perpustakaan dan diharapkan bisa meningkatkan minat baca para siswa di MTs Negeri 1 Purworejo. 


\section{SIMPULAN}

Berdasarkan hasil penelitian dan pembahasan maka dapat disimpulkan bahwa manajemen perpustakaan di MTs Negeri 1 Purworejo dilakukan dari perencanaan, pengorganisasian, penggerakan, dan pengawasan, sebagai berikut :

a. Proses perencanaan pengelolaan secara tradisional atau belum secara konvensional. Tetapi pada tahun 2018, perpustakaan MTs Negeri 1 Purworejo sudah sedikit demi sedikit mengembangkan perpustakaan sehingga dijalankan secara tradisional dan konvensional. Perencanaan tersebut meliputi : Sumber Daya Manusia dan Sumber Daya Non Manusia berupa : layanan, koleksi, dan sarana pra sarana yang mendukung perpustakaan.

b. Pengorganisasian dalam manajemen perpustakaan sekolah sama dengan perpustakaan sekolah pada umumnya. Pengorganisasian tersebut meliputi : bentuk struktur organisasi, standar kualifikasi tenaga perpustakaan serta kesatuan komando dan koordinasi yang dipimpin oleh kepala madrasah dibantu oleh wakil kepala madrasah.

c. Proses penggerakan terkait proses kepemimpinan dilakukan oleh kepala madrasah dibantu oleh wakil kepala madarasah dan beberapa teknisi. Penggerakan terkait job description dilakukan dengan sendiri oleh kepala perpustakaan karena hanya satu orang yang mengelola serta penjelasan mengenai kebijakan yang diterapkan di perpustakaan dilakukan melalui komunikasi langsung, tinjauan langsung dari kepala madrasah.

d. Pengawasan dalam manajemen perpustakaan dilakukan pada Sumber Daya Manusia (SDM) dan sarana dan prasarana yang terkait dengan supervisi dilakukan oleh kepala madrasah dan kepala perpustakaan. Meskipun tidak 
ada standar pengawasan yang mengikat, dan tidak adanya pembuatan laporan bulanan maka disini sebagai bentuk tanggung jawab kepala perpustakaan pada saat rapat evaluasi yang dilakukan sebulan sekali disanalah kepala perpustakaan menyampaikan masalah yang terjadi di dalam perpustakaan dan mencari solusi terbaik dari permasalahan tersebut.

Dengan demikian konsep manajemen perpustakaan di MTs Negeri 1 Purworejo masih dalam proses perkembangan menuju kea rah yang lebih baik. Dalam kaitannya dengan minat baca anak, perpustakaan MTs Negeri 1 Purworejo bisa dikatakan masih kurang, karena sebagian besar para siswa belum tertarik untuk membaca buku. Untuk meningkatkan minat baca siswa, sebaiknya dari semua teknisi perpustakaan bisa menggunakan alternative yang kreatif sehingga para siswa bisa lebih nyaman untuk membaca di perpustakaan dan dapat menambah wawasan siswa tersebut. 


\section{DAFTAR PUSTAKA}

adi wibowo. 2019. "INTEGRASI MANAJEMEN KESISWAAN PENDIDIKAN FORMAL DAN NON FORMAL DI PONDOK PESANTREN AN-NAWAWI BERJAN PURWOREJO." Jurnal Isema: Islamic Educational Managemen 4 (2): 210.

Adi Wibowo. 2019. "PENGGUNAAN MEDIA SOSIAL SEBAGAI TREND MEDIA DAKWAH PENDIDIKAN ISLAM DI ERA DIGITAL." JURNAL ISLAM NUSANTARA 3 (2).

Eko Prayogo, Suyadi. 2019. “Pembelajaran Pendidikan Agama Islam di Era Revolusi 4.0.Dengan Pendekatan Humanistik di SMP Muhammadiyah Al Mujahidin Gunung Kidul." At-Tarbiyat:Jurnal Pendidikan Islam 2 (2). https://doi.org/10.2105/ccdml.2868.002.

Hadi Santoso. 2019. “IMPLEMENTASI PENDIDIKAN KARAKTER DALAM KELUARGA MUSLIM (Sebuah Pendekatan Sosiologis)." Jurnal At-Tarbiyat: Jurnal Pendidikan Islam 2 (1): 1-24.

Ibrahim, Andi. 2014. "Konsep Dasar Manajemen Perpustakaan Dalam Mewujudkan Mutu Layanan Prima Dengan Sistem Temu Kembali Informasi Berbasis Digital." Desember vol.2 (No.2): 129-38.

Indhra Musthofa. 2019. "MODERNISASI PENDIDIKAN ISLAM PESANTREN DALAM TINJUAN FILOSOFIS METODOLOGIS." At-Tarbiyat:Jurnal Pendidikan Islam 2 (2). https://doi.org/10.2105/ccdml.2868.002.

Meriani, Rustam. 2018. "HIJRI-Jurnal Manajemen Pendidikan dan Keislaman." Manajemen Perpustakaan 7 (1): 51.

Moch. Tohet, Ida Rositha. 2019. “Penguatan Kurikulum 2013 dalam Menumbuhkan Karakter Peserta Didik di Sekolah." Jurnal At-Tarbiyat: Jurnal Pendidikan Islam 2 (2): 200-219.

Muhlil Musolin. 2019. "Sadd Adz-Dzarâi': Konsep dan Aplikasi Manajemen Pendidikan Islam." Manageria 4 (1): 71-84.

Pitaloka, Pranandia Popi. 2019. "Memupuk Minat Baca Anak." IQRA : Jurnal Ilmu Perpustakaan dan Informasi (e-Journal) 12 (2): 26-29. https:// doi.org/10.30829/iqra.v12i2.3981.

Rokan, M. Reza. 2017. “Jurnal Iqra'." Manajemen Perpustakaan Sekolah 11 (01): 88100.

Subaidi. 2019. “Manajemen Biaya dan Sarana Prasarana di SMA N 3 Pati dan 
Silahul Ulum Asempapan Trangkil Pati." Jurnal At-Tarbiyat: Jurnal Pendidikan Islam Vol. 02 (01): 71-72.

Wibowo, Adi. 2018. "Study Komparasi Penyelenggaraan Pendidikan SMK ( Studi Kasus SMK Di Pondok Pesantren Lirboyo Al-Mahrusiyah Dan Di SMK PGRI 2." At-Tarbiyat:Jurnal Pendidikan Islam 1 (1): 1-15. 